\title{
Chemical and Antidiarrheal Studies of Plinia cauliflora
}

\author{
Tatiana M. Souza-Moreira, Juliana A. Severi, Emerson Santos, ${ }^{1}$ Viviana Y.A. Silva, \\ Wagner Vilegas, ${ }^{2}$ Hérida R.N. Salgado, and Rosemeire C.L.R. Pietro ${ }^{1}$ \\ ${ }^{1}$ Department of Drugs and Medicines, School of Pharmaceutical Sciences of Araraquara; and ${ }^{2}$ Department of Organic Chemistry, \\ Institute of Chemistry; São Paulo State University, Araraquara, São Paulo, Brazil.
}

\begin{abstract}
Plinia cauliflora (Mart.) Kausel, widespread in South America, has edible fruits, and its bark is commonly used against diarrhea and other disorders, on account of its astringency. Because diarrhea is still one of the most important causes of illness and death among children in developing countries, where the population turns to traditional medicine for its treatment, the present study determined the composition of fruit and leaf extracts of $P$. cauliflora, analyzed the activity against diarrhea by antimicrobial and gastrointestinal motility, and evaluated the cytotoxicity of the extracts. Chemical composition was determined by high-performance liquid chromatograpy-ultraviolet/photodiode array detection. Antimicrobial activity was analyzed by agar diffusion and the microdilution method against etiological agents of diarrhea. The effect on gastrointestinal motility was analyzed using an experimental model in mice. Cytotoxicity was evaluated in vitro with the fibroblast cell line SIRC CCL 60, and leaf extract showed a 50\% inhibitory concentration of $0.48 \mu \mathrm{g} / \mathrm{mL}$. Gallic acid, ellagic acid, and flavonoid derivatives were detected in the extracts. It was observed that fruit and leaf extracts showed some activity against Enterococcus faecalis, Escherichia coli, Salmonella sp., and Shigella sp. However, neither extract had any effect on gastrointestinal motility.
\end{abstract}

KEY WORDS: • antimicrobial $\bullet$ cytotoxicity $\bullet$ ellagic acid $\bullet$ flavonoids $\bullet$ gallic acid $\bullet$ gastrointestinal motility $\bullet$ Plinia cauliflora

\section{INTRODUCTION}

D IARRHEA IS STILL one of the most important causes of morbidity and mortality among children under 5 years in developing countries. This intestinal disease results in loss of fluid and electrolytes, leading to serious dehydration and possibly death. ${ }^{1}$

Epidemiologically, a high incidence of acute diarrhea in children is associated with several factors, such as duration of maternal breast feeding, food and environmental contamination, maternal education, home location, family income, weight of infant at birth, access to treated water, and basic sanitary conditions. ${ }^{1,2}$

In developed countries, the commonest etiological agent is rotavirus, whereas in developing countries certain bacteria are the major causes. ${ }^{3-5}$ Escherichia coli, mainly of the enteropathogenic strains, is the main bacterial cause identified in many studies of urban populations in developing countries. ${ }^{1,4,6}$ The second commonest etiological agent isolated are Shigella spp., predominantly Shigella flexneri

Manuscript received 1 October 2010. Revision accepted 11 May 2011.

Address correspondence to: Rosemeire C.L.R. Pietro, Laboratório de Biotecnologia Farmacêutica, Department of Drugs and Medicines, School of Pharmaceutical Sciences of Araraquara, São Paulo State University, Rod. Araraquara-Jaú, km 1, Araraquara, SP, 14801-902, Brazil, E-mail: pietrorc@fcfar.unesp.br and Shigella sonnei. ${ }^{4,5}$ Salmonella sp., Campylobacter $\mathrm{sp}$. , and Yersinia sp. are of less importance as bacterial causes of diarrhea, but they are isolated in some cases. ${ }^{1,4,7}$

Bacterial agents that frequently cause diarrhea in Brazil are enteropathogenic E. coli, enterotoxigenic E. coli, Shigella sp., Salmonella sp., and Campylobacter sp. ${ }^{4,8}$

Generally, people who suffer most from diarrhea are socially underprivileged, almost without access to allopathic medicine, and for that reason turn to the use of plants like Psidium guajava L. ("guava tree") and Eugenia uniflora L. ("pitanga fruit tree"), both in the Myrtaceae family. Studies of leaf extracts from those species confirmed the antidiarrheal effects of increasing water absorption in the intestine and reducing gastrointestinal propulsion, relative to the control group. ${ }^{9}$

Plinia cauliflora (Mart.) Kausel, a tree belonging to the Myrtaceae family, has a popular edible fruit known as jaboticaba. It is native to forests of Brazil, Argentine, and Paraguay. The bark is commonly used for its astringency ${ }^{10}$ and is popularly used in the treatment of diarrhea. ${ }^{11}$ The main constituents of the fruit are sugars in the pulp, minerals, starch in the seeds, ${ }^{12}$ vitamin $\mathrm{C}$, and derivatives of anthocyanin such as cyanidin-3-glucoside. ${ }^{13}$

Despite widespread consumption and medicinal use, there is a lack of chemical and biological studies of $P$. cauliflora. In the search for new drugs against diarrhea related to the secondary metabolites, the efficacy of the crude fruit and 
leaf extracts of $P$. cauliflora was investigated by phytochemical analysis, antibacterial activity, and gastrointestinal motility.

\section{MATERIALS AND METHODS}

\section{Plant material}

Fruits and leaves of $P$. cauliflora (Mart.) Kausel (Family Myrtaceae), collected from São Carlos, Brazil $\left(22^{\circ} 01^{\prime} 16.6^{\prime \prime} \mathrm{S} ; 47^{\circ} 53^{\prime} 57.0^{\prime \prime} \mathrm{W}\right)$, in 2004 , were identified by Marcos Sobral and deposited at the herbarium of the Escola Superior de Agricultura "Luiz de Queiroz," Piracicaba, Brazil (voucher number ESA 96038).

\section{Microorganisms}

Reference strains Enterococcus faecalis ATCC 29212, E. coli ATCC 25922, Salmonella sp. ATCC 19196, and S. sonnei (clinical sample) were used. They were maintained on slants of brain-heart infusion (BHI) agar at $4^{\circ} \mathrm{C}$ and were activated in $\mathrm{BHI}$ broth at $37^{\circ} \mathrm{C}$ for 24 hours.

\section{Extract preparation}

Fruits and leaves were dried at $40^{\circ} \mathrm{C}$ and powdered. The powdered plant material was exhaustively extracted by percolation at room temperature with $70 \%$ aqueous ethanol. The extracts were filtered, concentrated under reduced pressure, frozen, and lyophilized, yielding 30\% (wt/wt) of fruit extract and leaf extract.

\section{Chromatographic characterization}

The constituents of each extract were initially analyzed by thin-layer chromatography on plates coated with Merck (Darmstadt, Germany) silica gel 60 F254 (0.2 mm thick) and eluted in three different solvent systems: chloroform/methanol/water (43:37:20 by volume), chloroform/methanol $/ n$ propanol/water (5:6:1:4 by volume), and $n$-butanol/acetic acid/water (4:1:5 by volume, organic phases). The thin-layer chromatography plates were sprayed with anisaldehydesulfuric acid or $1 \%$ ferric chloride in methanol. Spots were revealed by heating or under ultraviolet (UV) light. ${ }^{14}$

In addition, the extracts were also analyzed by high-performance liquid chromatography (HPLC) coupled to photodiode array (PDA) detection. The samples $(10 \mathrm{mg})$ were dissolved in $1 \mathrm{~mL}$ of pure water, subjected to solid-phase extraction on a Sep-Pak RP18 cartridge (200 mg), and eluted with methanol:water (8:2, vol/vol). The eluents were filtered (pore size, $0.22 \mu \mathrm{m}$ ) through a polytetrafluoroethylene membrane filter and subjected to HPLC-PDA analysis. The chromatographic profiles of the solid-phase extracted-treated samples were obtained with a Varian (Walnut Creek, CA, USA) ProStar 210/330 HPLC system equipped with a Rheodyne (Cotati, CA, USA) model 7125 sample injector with a $20 \mu \mathrm{L}$ sample loop. The analytical column was a Phenomenex (Torrance, CA, USA) Synergi Hydro RP18 $(250 \times 4.6 \mathrm{~mm}$ i.d.; particle size, $4 \mu \mathrm{m})$ equipped with a Phenomenex security guard column $(4.0 \times 2.0 \mathrm{~mm}$ i.d. $)$. The gradient mobile phase consisted of water (eluent $\mathrm{A}$ ) and acetonitrile (eluent B), both containing $0.05 \%$ trifluoroacetic acid. The gradient program was as follows: $4-25 \%$ B for 20 minutes, 40-80\% B for 40 minutes, and $80-95 \%$ B for 50 minutes. The flow rate was $1.0 \mathrm{~mL} /$ minute, and the total run time was 50 minutes. The difference between run time and program time corresponds to the conditioning and cleaning of the column. Eluted peaks were monitored by PDA scanning from 200 to $600 \mathrm{~nm}$. All the solvents used were HPLC grade.

\section{Quantification of chemical compounds}

Total phenolic compounds present in the extracts were analyzed using the Folin-Ciocalteau method. ${ }^{15,16}$ The method used consisted of adding 100 and $200 \mu \mathrm{L}$ of a stock solution of the extracts at $1 \mathrm{mg} / \mathrm{mL}$ to $7.5 \mathrm{~mL}$ of distilled water, $0.5 \mathrm{~mL}$ of Folin-Ciocalteau reagent (in aqueous solution at $10 \%[\mathrm{vol} / \mathrm{vol}])$, and $1.0 \mathrm{~mL}$ of aqueous sodium carbonate $(0.75 \%$ [wt/vol] $)$ and then completing the final volume to $10 \mathrm{~mL}$ with distilled water. Absorbance was measured after 3 hours at $760 \mathrm{~nm}$ in a spectrophotometer (model UV-1603, Shimadzu, Tokyo, Japan). A standard curve was plotted using different concentrations of an aqueous solution of tannic acid. Total tannin concentrations were determined by the casein precipitation method, which consisted of adding $0.1 \mathrm{~g}$ of powdered casein to $0.6-\mathrm{mL}$ samples of extracts diluted with $1.2 \mathrm{~mL}$ of distilled water and agitation for 3 hours at room temperature $\left(25^{\circ} \mathrm{C}\right)$. Then, the mixtures were centrifuged, and $500 \mu \mathrm{L}$ of the supernatants was diluted 1:1 with distilled water. Aliquots of $500 \mu \mathrm{L}$ of those solutions were then tested for residual phenolic compounds using the Folin-Ciocalteau method. The quantity of tannins corresponds to the difference in the absorption of these casein-precipitated samples and those obtained in the total phenol analysis. The quantity of total phenols and tannins are expressed in milligrams per gram of dry extract. The flavonoid content was estimated by the $\mathrm{AlCl}_{3}$ method. ${ }^{17}$ Quercetin was used to make the calibration curve. Two milliliters of a stock solution of the extracts at $1 \mathrm{mg} / \mathrm{mL}$ was added to $2 \mathrm{~mL}$ of $2 \%$ methanolic $\mathrm{AlCl}_{3} \cdot 6 \mathrm{H}_{2} \mathrm{O}$ solution. After incubation at room temperature for 15 minutes, the absorbance of the reaction mixture was measured at $430 \mathrm{~nm}$ with a spectrophotometer (model UV-1603, Shimadzu), and the flavonoid content was expressed in milligrams per gram. ${ }^{18}$

\section{Agar diffusion method}

Agar disk diffusion was used to determine the activity of extracts against the reference strains of bacteria. ${ }^{19}$ For these assays the extracts were dissolved in dimethyl sulfoxide to $200 \mathrm{mg} / \mathrm{mL}$. This method was used to determine activity of the extracts against the bacteria tested. An inoculum suspension was prepared to match 0.5 on the McFarland scale $\left(1.5 \times 10^{8}\right.$ colony-forming units $\left./ \mathrm{mL}\right)$, diluted in MuellerHinton agar to $1: 100$ (10 $0^{6}$ colony-forming units/mL). Steel templates with six wells $6 \mathrm{~mm}$ in diameter were placed on the solid medium, and $100 \mu \mathrm{L}$ of the extracts $(50 \mathrm{mg} / \mathrm{mL}$ 
diluted in dimethyl sulfoxide:BHI medium, 1:2 vol/vol), $100 \mu \mathrm{L}$ of dimethyl sulfoxide:BHI medium $(1: 2 \mathrm{vol} / \mathrm{vol})$ (negative control), and $50 \mu \mathrm{L}$ of ampicillin solution $(50 \mu \mathrm{g} /$ $\mathrm{mL})$ or $50 \mu \mathrm{L}$ of chloramphenicol solution $(50 \mu \mathrm{g} / \mathrm{mL})$ were separately added to each well. After 2 hours at $4^{\circ} \mathrm{C}$, the plates were incubated at $37^{\circ} \mathrm{C}$ for 24 hours. Bacterial growth inhibition was determined by diameter of the inhibition zone around each well, measured with digital calipers. The experiments were performed in triplicate.

\section{Minimal inhibitory concentration and minimal bactericidal concentration}

Minimal inhibitory concentration (MIC) values were determined by the microdilution method. ${ }^{20}$ The extract solutions were diluted with BHI broth (1:5 vol/vol), with the final test concentrations ranging from $10.000 \mathrm{mg} / \mathrm{mL}$ to $0.078 \mathrm{mg} / \mathrm{mL}$. The wells of 96-well microplates were filled with $100 \mu \mathrm{L}$ of BHI broth, and $100-\mu \mathrm{L}$ extract solutions, individually diluted with $\mathrm{BHI}$ broth, were added to the first well of each microplate line, starting a 1:1 ( $\mathrm{vol} / \mathrm{vol})$ serial dilution. Next, $100-\mu \mathrm{L}$ bacterial suspensions, separately, were added, reaching a final concentration of $2.5 \times 10^{5}$ colony-forming units $/ \mathrm{mL}$. The microplates were incubated aerobically at $37^{\circ} \mathrm{C}$ for 24 hours. Ampicillin and chloramphenicol (for Salmonella sp.) were used as positive controls at concentrations ranging from $12.500 \mu \mathrm{g} / \mathrm{mL}$ to $0.013 \mu \mathrm{g} /$ $\mathrm{mL}$. Bacterial growth was indicated by addition of $0.01 \%$ resazurin aqueous solution, and MIC values were identified as the lowest extract or reference drug concentration at which no growth was indicated by a change in color of resazurin from blue (absence of growth) to pink (growth). ${ }^{21}$ Minimal bactericidal concentration (MBC) values were determined by re-inoculating on Mueller-Hinton agar plates a sample of each dilution from the microplates that had been incubated at $37^{\circ} \mathrm{C}$ for 24 hours and were defined as the lowest concentration of the extract or reference drug at which microorganisms were completely killed. The experiments were performed in triplicate.

\section{Test for gastrointestinal motility (charcoal meal) in mice}

Gastrointestinal motility was assayed as described by Janssen and Jageneau, ${ }^{22}$ Wong and Way, ${ }^{23}$ and Salgado et al. ${ }^{24}$ Extracts were dissolved with sterile water to a concentration of $60 \mathrm{mg} / \mathrm{mL}$. Forty adult female albino Swiss mice (Mus domesticus domesticus), weighing between 24 and $30 \mathrm{~g}$, were selected and housed in polypropylene cages $(30 \times 20 \times 13 \mathrm{~cm})$ under standard conditions $\left(21 \pm 1^{\circ} \mathrm{C}\right.$ with a 12:12-hour reversed light-dark cycle and relative humidity 50-60\%) for 10 days before the experiment. Mice had free access to water and normal commercial laboratory diet (Purina, Ribeirão Preto, Brazil). Experiments were performed in compliance with the U.S. National Institutes of Health's Guide for the Care and Use of Laboratory Animals from the Institute of Laboratory Animal Resources and were approved (Resolution 24/2004) by the Ethical Committee of the School of Pharmaceutical Sciences, São Paulo State University (Araraquara, São Paulo). On the day of the test, the animals were divided into four groups of 10 mice each. They were weighed and deprived of food, with free access to water. Three hours after food deprivation, the animals in two groups were treated by gavage with, respectively, fruit and leaf extracts of $P$. cauliflora $(60 \mathrm{mg} / \mathrm{mL})$ at $1,000 \mathrm{mg} / \mathrm{kg}$, whereas the negative control group received $0.9 \% \mathrm{NaCl}$ sterile solution, and the positive control group received $5 \mathrm{mg} / \mathrm{kg}$ loperamide hydrochloride. Ninety minutes after the treatment, $0.4 \mathrm{~mL}$ of $10 \%$ aqueous suspension of charcoal powder in 5\% gum acacia was administered to each animal orally. The animals were sacrificed 45 minutes later in a $\mathrm{CO}_{2}$ chamber, and the abdomen was opened. The percentage of the length of the small intestine (from the pylorus to the cecum) traveled by the charcoal plug was determined.

\section{Cytotoxicity assay}

Cells of the rabbit corneal cell line (SIRC) ATCC CCL 60 were plated in 96-well microplates at a concentration of $1 \times 10^{5}$ cells $/ \mathrm{mL}$ in minimal essential medium containing $10 \%$ fetal bovine serum, $0.2 \%$ sodium bicarbonate, and sodium pyruvate. They were allowed to reach confluence for 72 hours in a $5 \% \mathrm{CO}_{2}$ incubator at $37^{\circ} \mathrm{C}$. The medium containing the extracts at a concentration ranging from 2,000 to $0.002 \mu \mathrm{g} / \mathrm{mL}$ was added, and the plates were incubated for 24 hours in a $5 \% \mathrm{CO}_{2}$ incubator at $37^{\circ} \mathrm{C}$. Resazurin at $0.01 \%$ was added to each well and evaluated after 4 hours using a fluorescence spectrophotometer (SpectraFluorPlus, Tecan, Maennedorf, Switzerland) with a stirrer at an excitation wavelength of $530 \mathrm{~nm}$ and an emission wavelength of $590 \mathrm{~nm} .^{25,26}$ The experiment was done in triplicate.

\section{Statistical analysis}

The results are expressed as mean \pm SD values. Statistical significance was tested using a Student's $t$ test. A difference was taken to be significant at $P<.05$.

\section{RESULTS}

Phytochemical screening by thin-layer chromatography indicated the presence mainly of phenolic compounds in both extracts, according to the colored spots after spraying. The HPLC-UV/PDA analysis confirmed that both extracts roughly contained the same type of phenolic compounds, although qualitative differences in the number of peaks were observed. Fractions were monitored at $254 \mathrm{~nm}$ for general aromatics and at $360 \mathrm{~nm}$ for flavonoid derivatives and compared with standard compounds under the same conditions of analysis. Figure 1A shows the chromatographic profile of leaf extract, exhibiting peaks belonging to three main groups of phenolic compounds. The peaks eluted at retention times $\left(R_{t}\right)$ in the range 10.2-25.2 minutes have the UV maximum around 275 and $285 \mathrm{~nm}$, typical of hydrolyzable tannins, ${ }^{27}$ while in the region of $R_{t} 25.2-34.2 \mathrm{~min}$ utes, there were intense UV bands at 252 and $363 \mathrm{~nm}$, indicative of ellagic acid derivatives, ${ }^{28}$ and for the last group, in the region of $R_{t} 34.2-40.5$ minutes, the UV 


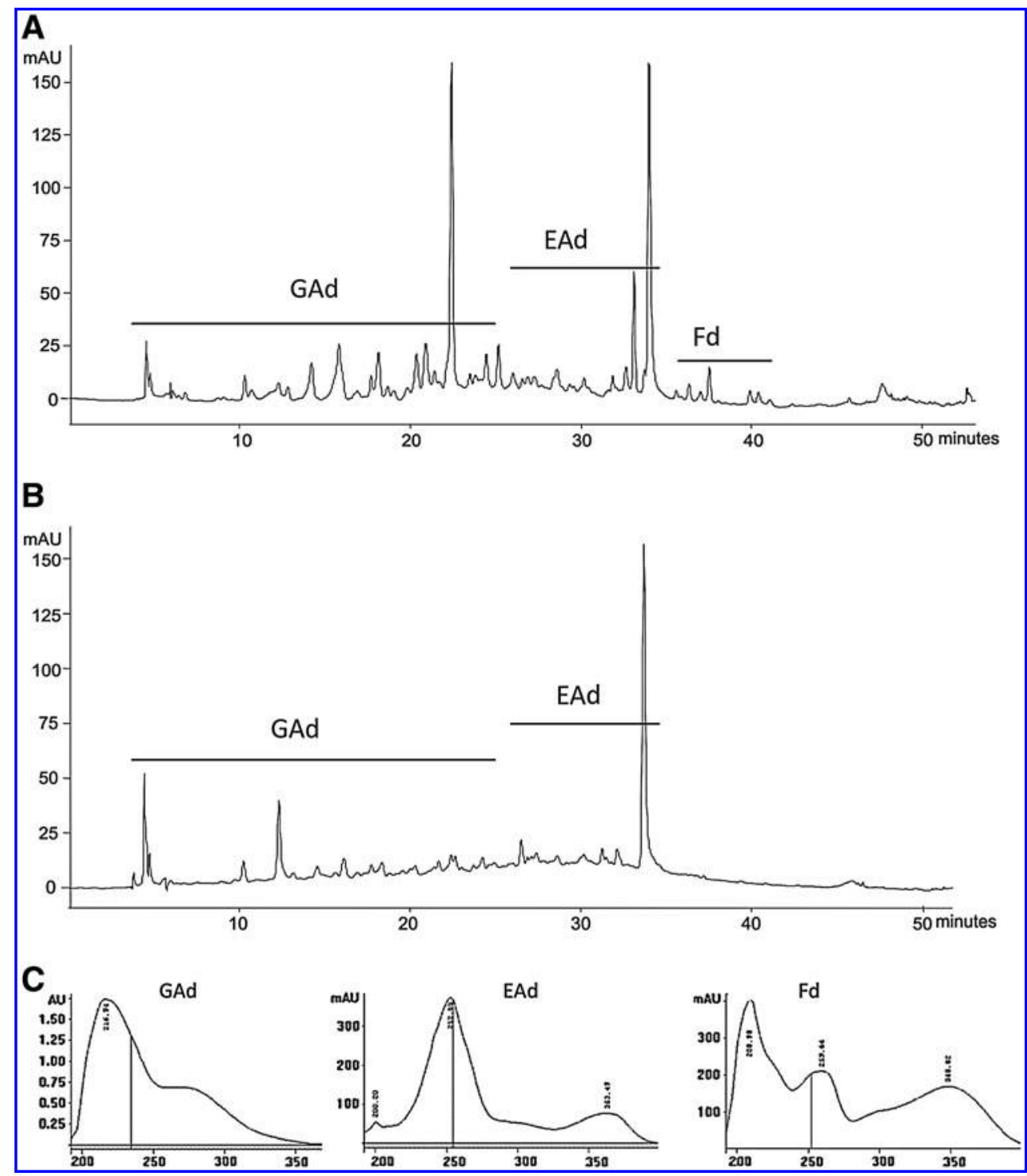

FIG. 1. High-performance liquid chromatography-photodiode array detection profile of ethanolic extracts of P. cauliflora: (A) leaves, (B) fruits, and (C) representative ultraviolet spectrum of eluted peaks. EAd, ellagic acid derivative; $\mathrm{Fd}$, flavonoid derivative; $\mathrm{Gad}$, gallic acid derivative; mAU, milliabsorbance units.

spectrum displays maximum absorption at 259 and $348 \mathrm{~nm}$, typical for flavonoids. ${ }^{29}$ Figure 1B exhibits the chromatographic profile of fruit extract, which exhibited the same peaks corresponding to hydrolyzable tannins and ellagic acid derivatives as those found in leaf extract, whereas flavonoids were not detected. Figure 1C represents the UV spectra of eluted peaks of gallic acid, ellagic acid, and flavonoids.

Leaf extract had $635 \mathrm{mg} / \mathrm{g}$ total phenols, $509 \mathrm{mg} / \mathrm{g}$ tannins, and $1 \mathrm{mg} / \mathrm{g}$ flavonoids, whereas fruit extract had $14 \mathrm{mg} / \mathrm{g}, 9.4 \mathrm{mg} / \mathrm{g}$, and $0.06 \mathrm{mg} / \mathrm{g}$, respectively. These data show the majority of phenolic compounds exist in leaf extract.

Fruit and leaf extracts had activity at $50 \mathrm{mg} / \mathrm{mL}$ against all the bacteria tested. Leaf extract had better activity than fruit extract, as shown in Table 1. E. faecalis showed higher susceptibility to both extracts, whereas $S$. sonnei showed the least.

MIC and MBC values are shown in Table 1. The fruit extract showed no inhibition at the highest concentration
$(10.00 \mathrm{mg} / \mathrm{mL})$ tested against all the bacteria. However, leaf extract did show inhibition at the concentration of $5.00 \mathrm{mg} /$ $\mathrm{mL}$ against all bacteria, indicating that it had better activity than fruit extract, which corroborated the sensitivity results obtained by agar diffusion.

The percentage distance traveled by the charcoal plug in the groups is shown in Table 2 .

The effect of the extracts did not decrease significantly the gastrointestinal motility at the concentration tested.

Leaf extract showed higher cytotoxicity than fruit extract. Meanwhile, leaf extract showed a 50\% inhibitory concentration of $0.48 \mu \mathrm{g} / \mathrm{mL}$, whereas fruit extract did not show toxicity at the higher concentration tested.

\section{DISCUSSION}

Because of the popular use of $P$. cauliflora against diarrhea, the present study was carried out to investigate the potential activity of fruit and leaf extracts as an effective aid in the treatment of this disease. 
Table 1. Antimicrobial Activity of P. CaUliflora Extracts

\begin{tabular}{|c|c|c|c|c|c|c|c|c|}
\hline \multirow[b]{2}{*}{ Sample } & \multicolumn{4}{|c|}{ Inhibition zone $e^{\mathrm{a}}$} & \multicolumn{4}{|c|}{$M I C / M B C$} \\
\hline & E. coli & E. faecalis & Salmonella sp. & S. sonnei & E. coli & E. faecalis & Salmonella sp. & S. sonnei \\
\hline Fruit extract ${ }^{b}$ & $8.5 \pm 0.7$ & $19.7 \pm 1.4$ & $10.4 \pm 1.6$ & $8.8 \pm 0.8$ & $>10.0 />10.0$ & $>10.0 />10.0$ & $>10.0 />10.0$ & $>10.0 />10.0$ \\
\hline Leaf extract ${ }^{\mathrm{b}}$ & $18.1 \pm 2.0$ & $20.7 \pm 2.3$ & $14.9 \pm 2.0$ & $10.0 \pm 1.7$ & $5.0 / 5.0$ & $5.0 / 5.0$ & $5.0 / 5.0$ & $5.0 / 5.0$ \\
\hline Ampicillin ${ }^{\mathrm{c}}$ & $16.7 \pm 0.6$ & $17.7 \pm 0.8$ & $\mathrm{NE}$ & $12.0 \pm 1.7$ & $0.4 / 0.8$ & $0.4 / 0.4$ & $\mathrm{NE}$ & $3.1 / 3.1$ \\
\hline Chloramphenicol $^{\mathrm{c}}$ & $\mathrm{NE}$ & $\mathrm{NE}$ & $12.5 \pm 0.7$ & $\mathrm{NE}$ & $\mathrm{NE}$ & $\mathrm{NE}$ & $625 / 1,250$ & $\mathrm{NE}$ \\
\hline
\end{tabular}

${ }^{\mathrm{a}}$ Values are expressed in millimeters as mean $\pm \mathrm{SD}$ of three determinations.

${ }^{\mathrm{b}}$ Minimal inhibitory concentration (MIC) and minimal bactericidal concentration (MBC) values are expressed in $\mathrm{mg} / \mathrm{mL}$.

${ }^{\mathrm{c}} \mathrm{MIC}$ and $\mathrm{MBC}$ values are expressed in $\mu \mathrm{g} / \mathrm{mL}$.

$\mathrm{NE}$, not evaluated.

The HPLC-UV/PDA analysis provided the chemical profiles of $P$. cauliflora leaf and fruit extracts. The active compounds present were identified as gallic acid, ellagic acid, and flavonoid derivatives. These results are consistent with some published data on the chemical composition of plants belonging to the Myrtaceae family. For example, aerial parts of Plinia glomerata exhibited the presence of ellagic acid derivatives, ${ }^{30}$ whereas Plinia pinnata showed flavonoid derivatives, ${ }^{31}$ and the methanolic extracts of many fruits of the Myrtaceae family have already been studied for their hydrolyzable tannin and flavonoid content. ${ }^{32}$

Quantification of chemical compounds indicated that both extracts have phenolic compounds, mainly flavonoids, and tannins that were present in higher concentrations in leaf extract than in fruit extract. Flavonoid content in fruit extract was more than 10 times smaller compared with leaf extract, and that minimum content was not significant when analyzed by HPLC-PDA/UV profile.

Antimicrobial activity exhibited by plants has been attributed to the presence of tannins, flavonoids, and terpenes. ${ }^{33-35}$ As examples, isolated compounds such as gallic acid from Caesalpinia mimosoides showed activity against Salmonella typhi and Staphylococcus aureus, ${ }^{36}$ ellagic acid derivatives from Irvingia gabonensis showed activity against bacteria and fungi, ${ }^{37}$ and flavonoid derivatives of Pericarpium Citri Reticulatae showed activity against E. coli, S. typhi, and Staphylococcus epidermidis. ${ }^{38}$ The results of the antimicrobial tests showed that the diarrhea agents $E$. faecalis, E. coli, Salmonella sp., and S. sonnei are weakly sensitive to fruit and leaf extracts of $P$. cauliflora. The leaf extract proved to be more powerful than the fruit and showed MIC and MBC values about $5.00 \mathrm{mg} / \mathrm{mL}$. The an-

Table 2. Effect of Plant Extracts on Gastrointestinal Motility

\begin{tabular}{lc}
\hline Treatment & Distance traveled by charcoal plug (\%) \\
\hline Saline & $49.47 \pm 5.35$ \\
Fruit extract & $50.72 \pm 9.96$ \\
Leaf extract & $44.15 \pm 13.48$ \\
Loperamide hydrochloride & $38.54 \pm 10.21 *$ \\
\hline
\end{tabular}

Data are mean \pm SD values ( $n=10$ per group).

$* P<.05$ versus the negative control (saline). timicrobial activity of these extracts might be attributed to the presence of phenolic substances revealed by the chromatographic fingerprint.

According to Almeida et al., ${ }^{9}$ a sample is considered antidiarrheic when it produces an inverse diarrheal effect, that is, when it decreases the secretion or increases the absorption of water and reduces intestinal motility. Havagiray et al. ${ }^{39}$ claimed that plants possessing alkaloids, flavonoids, saponins, steroids, and tannins show antidiarrheal activity. Flavonoids have an ability to inhibit intestinal motility and hydroelectrolytic secretions, ${ }^{40}$ and tannins precipitate proteins, reducing secretion and peristaltic movements. ${ }^{9,41}$ Gallic acid has already been cited for its antidiarrheic activity. ${ }^{42}$ The layer formed by proteins precipitated on the mucosal surface of the enterocytes can also inhibit the development of microorganisms, contributing to the antiseptic action of the tannins and aiding the treatment of diarrhea. ${ }^{9}$ Because derivatives of tannins were observed in the fruit and leaf extracts of $P$. cauliflora, an antidiarrheal effect could be expected in this plant material. However, there was no significant difference between the treated and control group of animals.

The World Health Organization initiated the Diarrhoea Disease Control Program to study traditional medical practices and related matters ${ }^{43}$ because diarrhea is one of the leading causes of childhood mortality in developing countries, causing 1.8 million deaths every year. ${ }^{44}$ Therefore, it would be valuable to identify and test commonly available natural drugs as alternative treatments for this disease, such as the plants that are widespread in South America. It should be stressed that a natural agent may act not only on intestinal motility but also against the etiological causes of diarrheabacteria, viruses, or protozoans.

Besides those considerations, it is very important that an extract with possible therapeutic use (unless against cancer) does not show toxicity, and a manner of screening this potential is by cytotoxicity assays. In this work, no antimicrobial nor antidiarrheic activity was shown, but the absence of cytotoxicity in fruit extract agrees with its main use as food. Studies indicated some cytotoxic effects of gallic acid, ${ }^{45}$ ellagic acid,${ }^{46}$ and flavonoid derivatives. ${ }^{47}$ As indicated, these compounds appear in higher levels in leaf than in fruit extract, which could provide leaf extract cytotoxicity. 
The present study is important to show secondary metabolites of hydroalcoholic extracts of $P$. cauliflora by this HPLC-UV/PDA method, which revealed mainly ellagic acid, gallic acid, and flavonoid derivatives, the quantification of their metabolite class, and the cytotoxicity of leaf extract.

\section{ACKNOWLEDGMENTS}

The authors thank Marcos Sobral for the identification of the plant material. We are grateful to Luís Eduardo dos Santos, Maria de Fátima Rodrigues, and Alessandra F. Sciasci for technical assistance. The authors are thankful to FAPESP, CAPES, and PADC-UNESP for financial support.

\section{AUTHOR DISCLOSURE STATEMENT}

No competing financial interests exist.

\section{REFERENCES}

1. Brandão MB, Lopes CE, Morcillo AM, Baracat ECE: O óbito em crianças com diarréia aguda e choque em UTI. Rev Assoc Med Bras 2005;51:237-240.

2. Morais TB, Morais MB, Sigulem DM: Bacterial contamination of the lacteal contents of feeding bottles in metropolitan São Paulo, Brazil. Bull World Health Organ 1998;76:173-181.

3. Abu-Elyazeed R, Wierzba TF, Mourad AS, et al.: Epidemiology of enterotoxigenic Escherichia coli diarrhea in a pediatric cohort in a periurban area of lower Egypt. J Infect Dis 1999;179:382-389.

4. Souza EC, Martinez MB, Taddei CR, et al.: Perfil etiológico das diarréias agudas de crianças atendidas em São Paulo. J Pediatr 2002;78:31-38.

5. Toporovski MS, Mimica I, Chieffi PP, Paschoalotti MA, Dias AM, Silva CB: Diarréia aguda em crianças menores de 3 anos de idade: recuperação de enteropatógenos nas amostras fecais de pacientes comparada à de grupo controle. J Pediatr 1999;75:97-104.

6. Fagundes Neto U, Scaletsky ICA: The gut at war: the consequences of enteropathogenic Escherichia coli infection as a factor of diarrhea and malnutrition. Sao Paulo Med J 2000;118:21-29.

7. Almeida MTG, Silva RM, Donaire LM, Moreira LE, Martinez MB: Enteropatógenos associados com diarréia aguda em crianças. J Pediatr 1998;74:291-298.

8. Moreno ACR, Fernandes Filho A, Gomes TdoA, et al.: Etiology of childhood diarrhea in the northeast of Brazil: significant emergent diarrheal pathogens. Diagn Microbiol Infect Dis 2010; 66:50-57.

9. Almeida CE, Karnikowski MGO, Foleto R, Baldisserotto B: Analysis of antidiarrhoeic effect of plants used in popular medicine. Rev Saude Publica 1995;29:428-433.

10. Lorenzi H: Árvores Brasileiras: Manual de Identificação e Cultivo de Plantas Arbóreas Nativas do Brasil, 3rd ed. Instituto Plantarum, Nova Odessa, Brazil, 2000.

11. Cruz AMV, Kaplan MAC: Uso medicinal de espécies das famílias Myrtaceae e Melastomataceae no Brasil. Floresta Ambiente 2004;11:47-52.

12. Barros RS, Finger FL, Magalhães MM: Changes in non-structural carbohydrates in developing fruit of Myrciaria jaboticaba. Sci Hortic 1996;66:209-215.
13. Einbond LS, Reynertson KA, Luo XD, Basile MJ, Kennelly EJ: Anthocyanin antioxidants from edible fruits. Food Chem 2004; $84: 23-28$.

14. Wagner H, Bladt S, Zgainski EM: Plant Drug Analysis. SpringerVerlag, Berlin, 1984.

15. Folin O, Ciocalteau V: On tyrosine and tryptophane determination in proteins. J Biol Chem 1927;73:424-427.

16. Monteiro JM, Albuquerque UP, Lins Neto EMF, Araújo EL, Albuquerque MM, Amorim ELC: The effects of seasonal climate changes in the Caatinga on tannin levels in Myracrodruon urundeuva (Engl.) Fr. All. and Anadenanthera colubrina (Vell.) Brenan. Rev Bras Farmacogn 2006;16:338-344.

17. Quettier-Deleu C, Gressier B, Vasseur J, et al.: Phenolic compounds and antioxidant activities of buckweat hulls and flour. $\underline{J}$ Ethnopharmacol 2000;72:35-42.

18. Djeridane A, Yousfi M, Nadjemi B, Boutassouna D, Stocker P, Vidal N: Antioxidant activity of some algerian medicinal plants extracts containing phenolic compounds. Food Chem 2006:97: 654-660.

19. Performance Standards for Antimicrobial Disk Susceptibility Tests. Approved Standard M2-A8. National Committee for Clinical Laboratory Standards, Wayne, PA, 2003.

20. Methods for Dilution Antimicrobial Susceptibility Tests for Bacteria That Grow Aerobically. Approved Standard M7-A6. National Committee for Clinical Laboratory Standards, Wayne, PA, 2003.

21. Gabrielson J, Hart M, Jarelöv A, Kuhn I, Mckenzie D, Möllby R: Evaluation of redox indicators and the use of digital scanners and spectrophotometer for quantification of microbial growth in microplates. J Microbiol Methods 2002;50:63-73.

22. Janssen P, Jageneau AH: A new series of potent analgesics. Part I-Chemical structure and pharmacological activity. $\underline{\text { J Pharm }}$ Pharmacol 1957;9:381-400.

23. Wong CL, Way MK: Effects of aspirin and paracetamol on naloxone reversal of morphine-induced inhibition of gastrointestinal propulsion in mice. Eur J Pharmacol 1981;73:11-19.

24. Salgado HRN, Roncari AFF, Moreira RRD: Antidiarrhoeal effects of Mikania glomerata Spreng. (Asteraceae) leaf extract in mice. Rev Bras Farmacogn 2005;15:205-208.

25. O'Brien J, Wilson I, Orton T, Pognan F: Investigation of the Alamar Blue (resazurin) fluorescent dye for the assessment of mammalian cell cytotoxicity. Eur J Biochem 2000;267:54215426.

26. Takahashi Y, Koike M, Honda H, et al:: Development of the short time exposure (STE) test: an in vitro eye irritation test using SIRC cells. Toxicol In Vitro 2008;22:760-770.

27. Salminen JP, Ossipov V, Loponen J, Haukioja E, Pihlaja K: Characterization of hydrolysable tannins from leaves of Betula pubescens by high-performance liquid chromatography-mass spectrometry. J Chromatogr A 1999;864:283-291.

28. Gallo MBC, Silva FC, Vieira PC, Fernandes JB, Silva MFGF: New natural products from Siphoneugena densiflora Berg (Myrtaceae) and their chemotaxonomic significance. $\underline{J \text { Braz }}$ Chem Soc 2006;17:279-288.

29. Mabry TJ, Markham KR, Thomas MB: The Systematic Identification of Flavonoids. Springer-Verlag, New York, 1970.

30. Serafin C, Nart V, Malheiros A, et al.: Avaliação do potencial antimicrobiano de Plinia glomerata (Myrtaceae). Rev Bras Farmacogn 2007;17:578-582. 
31. Mendez J, Hasegawa M, Bilia AR, Morelli I: 5,7,2',5'-Tetrahydroxydihydroflavonol 3-rhamnoside from Plinia pinnata. Phytochemistry 1994;36:1087-1088.

32. Reynertson KA, Yang H, Jiang B, Basile MJ, Kennelly EJ: Quantitative analysis of antiradical phenolic constituents from fourteen edible Myrtaceae fruits. Food Chem 2008;109:883-890.

33. Choi YM, Noh DO, Cho SY, et al:: Antioxidant and antimicrobial activities of propolis from several regions of Korea. Lebensm Wiss Technol 2006;39:756-761.

34. Souza TM, Severi JA, Silva VYA, Santos E, Pietro RCLR: Bioprospecção de atividade antioxidante e antimicrobiana da casca de Stryphnodendron adstringens (Mart.) Coville (Leguminosae-Mimosoidae). Rev Ciencias Farm Básica Aplicada 2007; 28:221-226.

35. Rodrigues J, Michelin DC, Rinaldo D, et al.: Antimicrobial activity of Miconia species (Melastomataceae). J Med Food 2008; 11:120-126.

36. Chanwitheesuk A, Teerawutgulrag A, Kilburn JD, Rakariyatham $\mathrm{N}$ : Antimicrobial gallic acid from Caesalpinia mimosoides Lamk. Food Chem 2007;100:1044-1048.

37. Kuete V, Wabo GF, Ngameni B, et al.: Antimicrobial activity of the methanolic extract, fractions and compounds from the stem bark of Irvingia gabonensis (Ixonanthaceae). J Ethnopharmacol 2007;114:54-60.

38. Yi Z, Yu Y, Liang Y, Zeng B: In vitro antioxidant and antimicrobial activities of the extract of Pericarpium Citri Reticulatae of a new Citrus cultivar and its main flavonoids. LWT 2008; 41:597-603.
39. Havagiray R, Ramesh C, Sadhna K: Study of antidiarrhoeal activity of Calotropis gigantea r.b.r. in experimental animals. $\underline{J}$ Pharm Pharmaceut Sci 2004;7:70-75.

40. Venkatesan N, Vadivu T, Sathiya N, et al:: Anti-diarrhoeal potential of Asparagus racemosus wild root extracts in laboratory animals. J Pharm Sci 2005;8:39-45.

41. Jia Q, Su W, Peng W, Li P, Wang Y: Anti-diarrhoea and analgesic activities of the methanol extract and its fractions of Jasminum amplexicaule Buch.-Ham. (Oleaceae). J Ethnopharmacol 2008;119:299-304.

42. Chen JC, Ho TY, Chang YS, Wu SL, Hsiang CY: Anti-diarrheal effect of Galla Chinensis on the Escherichia coli heat-labile enterotoxin and ganglioside interaction. $J$ Ethnopharmacol 2006;103:385-391.

43. World Health Organization: Programme for Control of Diarrhoeal Diseases, Ninth Programme Report 1992-1993. World Health Organization, Geneva, 1994.

44. World Health Organization: World Health Report. World Health Organization, Geneva, 2004, pp. 120-125.

45. Ishihara M, Sakagami H: Application of semiempirical method to estimate the cytotoxic activity of gallic acid and its related compounds. Anticancer Res 2003;23:2549-2552.

46. Ito A, Chai HB, Lee D, et al.: Ellagic acid derivatives and cytotoxic cucurbitacins from Elaeocarpus mastersii. Phytochemistry 2002;61:171-174.

47. Plochmann K, Korte G, Koutsilieri E, et al.: Structure-activity relationships of flavonoid-induced cytotoxicity on human leukemia cells. Arch Biochem Biophys 2007;460:1-9. 
This article has been cited by:

1. Junqing Zhang, Sheng Wang, Yonghui Li, Peng Xu, Feng Chen, Yinfeng Tan, Jinao Duan. 2013. Anti-diarrheal constituents of Alpinia oxyphylla. Fitoterapia 89, 149-156. [CrossRef]

2. Shi-Biao Wu, Chunlin Long, Edward J. Kennelly. 2013. Phytochemistry and health-benefits of jaboticaba, an emerging fruit crop from Brazil. Food Research International . [CrossRef]

3. A.J.S. Carvalho, T. Ishikawa, C.M.C.P. Gouvêa. 2012. Aqueous extract of Plinia edulis leaves: Antioxidant activity and cytotoxicity to human breast cancer MCF-7 cell line. South African Journal of Botany 81, 1-7. [CrossRef] 